\title{
Hvor gode leger vil vi ha?
}

Alt tyder på at turnustjenesten i sin nåværende form forsvinner. Et forslag om å erstatte den med en ny type begynnerstillinger for leger er ute på høring (2). Protestene har så langt ikke vært høylytte. Det er neppe fordi turnustjenesten ikke anses som viktig, snarere et uttrykk for at ordningen har fungert spesielt dårlig de siste årene og vært uforutsigbar for både de fremtidige legene, helsemyndighetene og arbeidsgiverne $(3,4)$. Det er enkelt å bli enige om utfordringene: Det er vanskelig å skaffe mange nok og gode nok turnusplasser, det er ventelister, økende andel særplasser, flere som ikke møter opp ved tildelt turnussted, dessuten kommer det stadig flere med utdanning fra utlandet til Norge. Utfordringen er ikke å peke på problemene, men å utforme en fullgod erstatning.

På mange måter har den norske turnustjenesten alltid vært et slags kompromiss og aldri helt funnet sin form. Den ble innført i 1955 for å kompensere for at medisinstudiet ble kortet ned fra åtte til 6,5 år. Men hva slags «tjeneste» var det? Var det utdanning eller arbeid? Mye skulle oppnås på én gang: praktisk opplæring i klinisk arbeid, full legedekning over hele landet, forutsigbarhet både for studentene og helsetjenesten som skulle motta dem. Det har vært kontroverser om målsetting og innhold helt fra starten (3). Men trass i dette er vi nok mange som ikke helt skjønner hvordan vi skulle blitt ferdige leger uten turnustjenesten. For meg var det å bli omplassert fra auditoriene på Rikshospitalet til mottakelsen på Hammerfest sykehus både dramatisk og intenst lærerikt. Selvsagt ikke like dramatisk som det var for generasjonen av leger før megda turnuskandidaten kunne oppleve å bli møtt av distriktslegen for deretter å bli etterlatt alene i en øykommune nordpå - men dramatisk nok. Jeg var ikke alene og hadde folk å spørre til råds. Men læringskurven var stupbratt og opplevelsene sitter spikret nå nesten 25 år senere.

Allerede i 1911 foreslo en studieplankomité ledet av Hjalmar Schiøtz å innføre obligatorisk praktisk tjeneste etter endt medisinstudium (3). Forslaget ble den gang ikke tatt til følge. Kjernen i problemet er: Du kan ikke lese deg til eller klikke deg frem til å bli en god lege. Du trenger også praktisk klinisk erfaring. Og vi snakker da ikke bare om ferdighetstrening i praktiske prosedyrer, men erfaring med faktiske pasienter, pårørerende og annet helsepersonell over tid, i reelle livssituasjoner. Når og hvordan skal man få denne erfaringen? Hvem skal betale for det? Og når er man god nok lege til å behandle syke mennesker på egen hånd? Det er disse spørsmålene diskusjonen rundt turnustjeneste og spesialistutdanning dreier seg om og som flere parter har berettigede meninger om: legene selv - som ønsker å bli best mulig kvalifisert, men samtidig ikke vil være ubetalte studenter lenger enn nødvendig, pasientene - som selvsagt vil ha leger med mest mulig kunnskap og erfaring, de ansvarlige for helsetjenesten - som bl.a. skal betale deler av regningen.
Dette er problemstillinger vi ikke er alene om. I USA gikk debatten høyt for noen år siden da det amerikanske autorisasjonskontoret for leger, the Accreditation Council for Graduate Medical Education, gikk til det - etter amerikanske forhold - drastiske skritt å kreve at arbeidstiden i forbindelse med «residency» (omtrent tilsvarende norsk turnustjeneste og spesialistutdanning) skulle begrenses til gjennomsnittlig 80 timer per uke. Mange mente at man umulig kunne tilegne seg tilstrekkelig kunnskap og erfaring med så kort arbeidstid. Det var ikke bare bekymring for at det ikke var tilstrekkelig tid totalt til å lære alt som var nødvendig, men også for at det ble altfor lite sammenhengende tid til å følge pasientene og se sykdomsforløp utvikle seg $(5,6)$.

Utdanning etter endt medisinstudium og frem til autorisert lege og spesialist har både i USA og Norge, som i de fleste andre land, i hovedsak vært basert på «learning by doing» og mester-svennprinsippet. Det gir mye og god læring, men begge metoder er arbeidsintensive. Det er klart at leger som nærmest bodde på sykehuset, ble dyktige - ikke minst når kollegene også gjorde det. Man fikk fulgt pasientene over tid, fikk erfaring med tilstander og forløp, fikk observere kollegene og seg selv i mange situasjoner. Problemstillingen nå er hvordan denne læringen kan og skal erstattes. Kombinasjonen av tøffe produktivitetskrav, betydelig kortere arbeidstid både for den som skal lære og for den som skal lære bort og en eksplosiv utvikling av medisinsk kunnskap og muligheter er krevende, men vi kommer ikke utenom å finne en løsning på problemet dersom vi skal sikre kvaliteten på helsetjenestene.

«What does it take to be good at something in which failure is so easy, so effortless?» spør Atul Gawande i boken Better: a surgeon's notes on performance (1). Gawande er generell kirurg ved Brigham and Women's Hospital i Boston, professor ved Harvard og fast bidragsyter til The New Yorker. Men først og fremst er han en åpen og observant kliniker som evner å omsette i prosa hva en leges hverdag dreier seg om. Det er dette spørsmålet vi også må besvare: Hvor gode leger vil vi ha i Norge, og hvordan utdanner vi dem?

\section{Charlotte Haug}

redaktør

\footnotetext{
Litteratur

1. Gawande A. Better: a surgeon's notes on performance. New York: Picador, 2007.

2. Helsedirektoratet. Nybyrjarstilling for legar - praktisk og pedagogisk oppfølging av nyutdanna legar. 2010. www.helsedirektoratet.no/personell/publikasjoner/ nybyrjarstilling (13.4.2010).

3. Brinchmann-Hansen $\AA$. 50 år i år ? lenge leve turnustjenesten? Tidsskr Nor Lægeforen 2004; 124: 2110-2.

4. Vik T. Turnustjenesten under press. Tidsskr Nor Legeforen 2008; 128: 1806.

5. Drazen JM, Epstein AM. Rethinking medical training - the critical work ahead. N Engl J Med 2002; 347: 1271-2.

6. Jones MD. More than a matter of time. Pediatrics 2004; 113: 1396-8.
} 